\title{
Contamination in Ontario Farmstead Domestic Wells and its Association with Agriculture
}

\section{Results from Drinking Water Wells}

\section{8}

\author{
M.J. GOSS ${ }^{1}$, D.A.J. BARRY ${ }^{1}$, and D.L. RUDOLPH ${ }^{2}$ \\ ${ }^{1}$ Centre for Land and Water Stewardship, \\ University of Guelph, Guelph, Ontario N1G 2W1. \\ 2 Department of Earth Sciences, \\ University of Waterloo, Waterloo, Ontario N2L 3G1
}




\begin{abstract}
Groundwater provides about $30 \%$ of water requirements in Ontario, but farm families depend almost entirely on private wells. Major potential contaminants on farms are nitrate $\left(\mathrm{NO}_{3}{ }^{-}\right)$, pathogenic micro-organisms, pesticides and petroleum derivatives. A survey of farm drinking water wells was conducted throughout the Province of Ontario, Canada, in 1991 and 1992 and tested for these contaminants. Main objectives of the survey were to determine the quality and safety of drinking water for farm families, and determine the effect of agricultural management on groundwater quality at a provincial scale.
\end{abstract}

Four farm wells were chosen in each township where $>50 \%$ of the land area was used for agricultural production. Elsewhere one well per township was usually sampled. Within each township the types of farming activity and dominant soils were additional criteria for selection. The network comprised 1292 of the estimated 500,000 water-wells in Ontario, and the study conformed to a stratified random survey. A subset of 160 wells, chosen by farm type, soil, and the presence or absence of a fuel storage tank, was investigated for the presence of petroleum derivatives: benzene, toluene, ethyl benzene, and xylene.

About $40 \%$ of farm wells tested contained one or more of the target contaminants above the maximum acceptable concentration; $34 \%$ of wells had more than the maximum acceptable number of coliform bacteria, $14 \%$ contained $\mathrm{NO}_{3}{ }^{-}-\mathrm{N}$ concentrations above $10 \mathrm{mg} \mathrm{L}^{-1}$ limit and about $7 \%$ were contaminated with both bacteria and $\mathrm{NO}_{3}{ }^{-}$. Only six wells contained pesticide residues above the interim maximum acceptable concentration (IMAC), but pesticides were detected in $7 \%$ of wells in winter and in $11 \%$ in summer. No wells contained detectable petroleum derivatives. These results for $\mathrm{NO}_{3}{ }^{-}$contamination were not significantly different from 
those reported for a survey of Ontario wells for the period 1950-1954, but the frequency of contamination by Escherichia coli was greater in the present study.

None of the point sources investigated contributed significantly to the $\mathrm{NO}_{3}{ }^{-}$contamination. The percentage of wells contaminated by coliform bacteria decreased significantly with increasing separation of the well from the feedlot or exercise yard on livestock farms. A full statistical model including the type of well construction, depth, age and soil hydrologic group was developed to describe the frequency of $\mathrm{NO}_{3}{ }^{-}$contamination. 


\section{Introduction}

Approximately $75 \%$ of the water used in Canada is taken from surface water sources. In Ontario groundwater provides about $30 \%$ of water requirements, but the rural population depends almost entirely on the extraction of groundwater by private wells. Monitoring of the quality of water consumed by the farm family is the responsibility of the householder and is not commonly reported. Consequently, the condition of rural groundwater resources is not well documented. Diffuse or non-point sources of contamination from intensive agriculture provide a potential threat to groundwater quality in the recharge areas of urban well fields. Nevertheless, the impact of agricultural land-use practices on regional groundwater quality is not well understood.

Some of the most common concerns for groundwater quality in relation to human health in the rural environment include contamination with pathogenic micro-organisms, nitrate and toxic organic compounds. On farms, the most frequently used groups of toxic organic chemicals are pesticides and petroleum derivatives; the latter being stored to fuel tractors and other machinery. Pesticides in storage or when handled in concentrated form represent a potential point source, as does a fuel tank. After application to the land or crops, pesticides form diffuse sources.

The obvious potential sources of pathogens on farms are livestock, and sewage treatment systems such as septic fields. Contamination of groundwater by livestock can result if run-off from manure storage or a feedlot yard percolates through the soil close to a well, or when manure is spread onto cropped land. Malfunctioning or poorly maintained septic systems have been the cause of many of the outbreaks of waterborne disease in the United States attributed to contaminated groundwater (Craun, 1984). 
Agricultural fields form the main diffuse sources of the $\mathrm{NO}_{3}{ }^{-}$that is leached to groundwater. However, $\mathrm{NO}_{3}{ }^{-}$is also released from septic systems (Keeney, 1989), exercise yards and manure storage facilities, which represent important potential point sources of contamination.

One method used to assess the quality of groundwater used by rural communities has been to document the occurrence of contaminants in domestic water wells. Several surveys conducted in Ontario and elsewhere have generally been designed to indicate the occurrence of specific target contaminants within a region of interest. Data from these surveys have been useful in gauging both the current state of a groundwater resource and in highlighting areas of particular concern. To develop strategies for minimizing the impact of agriculture on water resources, a more comprehensive understanding of the factors controlling contamination in rural areas is required.

To improve understanding of agricultural factors resulting in groundwater contamination, a rural water well survey was conducted throughout the Province of Ontario in 1991 and 1992. It focussed on the occurrence of $\mathrm{NO}_{3}{ }^{-}$, bacteria, selected pesticides and petroleum derivatives. The survey involved approximately 1300 farmstead domestic wells and 144 multilevel monitoring wells that were installed in selected farm fields as part of the study. The main objectives of the survey were to determine the quality and safety of drinking water for farm families relying on groundwater, and to determine the effect of agricultural management on the quality of groundwater. It was not intended to be an exhaustive study of groundwater quality throughout rural Ontario, but was designed to provide information at a provincial scale.

This paper describes the nature of the well survey including the site selection process, sampling protocols, and general statistics of water quality in the domestic farm wells. The results 
are examined with respect to agricultural land-use practices, hydrogeologic setting, and water well construction. Correlations between the occurrence of specific contaminants and the proximity of point- and non-point sources of contamination are discussed along with seasonal trends observed during two sampling episodes. Details of the results from analysis of the multilevel monitoring wells, and a comparison of the information gained from the two types of wells are given in Part 2 (Rudolph et al., 1998).

\section{Previous Groundwater Quality Surveys Using Domestic Wells}

Water well surveys can generally be classified on the basis of areal size or scale. Usually, the number of sampled wells reflects the scale of the surveyed area although in some exceptional cases, large numbers of wells have been sampled in a relatively small area in order to improve statistical validity of the data. Another main variable for well surveys is the set of contaminant species selected for analysis. In rural wells, nitrate, bacterial indicator species, and pesticides have

been most commonly measured, with some surveys focussing on an individual contaminant and others involving various combinations from the three groups.

Surveys of rural wells highlight the widespread presence of nitrate, bacteria and pesticide in groundwater (Tables $1 \& 2$ ). The proportion of wells that contain concentrations of contaminants that exceed acceptable values for drinking water are generally greatest for bacteria and least for pesticides, with the proportion of wells exceeding $10 \mathrm{mg} \mathrm{NO}_{3}^{-}-\mathrm{N} \mathrm{L}^{-1}$ being intermediate. The proportion of wells found to be contaminated with a particular species often varies according to the purpose and sampling strategy associated with a given survey.

In Ontario the oldest province-wide survey of domestic well water in rural areas was 
carried out from 1950-1954 (Table 1). An average of $13.8 \%$ of well water samples submitted in that period exceeded $10 \mathrm{mg} \mathrm{NO}_{3}{ }^{-} \mathrm{N} \mathrm{L}^{-1}$ (Johnston, 1955). From the data presented we have calculated that $14.9 \%$ of wells "registered positive evidence of pollution" with Escherichia coli, and $3.5 \%$ of wells were contaminated by bacteria and nitrate. More recent small-scale surveys have shown that the concentration of $\mathrm{NO}_{3}{ }^{-}$has exceeded the maximum acceptable value for drinking water in Ontario (10 $\left.\mathrm{mg} \mathrm{N} \mathrm{L}^{-1}\right)$ in approximately 5 to $20 \%$ of rural wells (Table 1 ). Surveys of bacteriological contamination in groundwater have been less common in Ontario than nitrate surveys, but recent studies suggest that the level of bacterial contamination (15 to $44 \%$ ) is much greater than for nitrate (Table 1).

Few surveys in Ontario have reported significant numbers exceeding the provincial interim maximum acceptable concentration (IMAC) for a given pesticide in drinking water (Table 1), hence many surveys report the frequency of detections. Variation in the limits of detection may explain some differences between surveys, but without a plot of cumulative frequency distribution of pesticide concentration in wells there is no way of knowing how much it does contribute. Random surveys have resulted in a much lower number of pesticide detections than have studies of areas suspected of pesticide contamination (Frank et al., 1987a; 1987b). Triazines, in particular atrazine, and acetanilide herbicides, were the most commonly detected pesticides in wells (Frank et al., 1987a; 1990). Frank et al. (1987a) found atrazine in 18.0\% of wells, and 2,4-D in 16.3\% of wells. Other pesticides detected were PCP (5.7\%), 2,4,5-T (4.2\%), dicamba (3.2\%), mecoprop (2.9\%), alachlor (2.5\%), simazine (2.5\%), dichlorprop (2.2\%), cyanazine $(1.5 \%)$, dinoseb (1.5\%), picloram (1.2\%), and MCPA (0.7\%).

Many surveys of well contamination with $\mathrm{NO}_{3}^{-}$have been undertaken in regions where 
climate, topography and land use are similar to those in Ontario. Between 2 and $22 \%$ of wells have been found to exceed $10 \mathrm{mg} \mathrm{N} \mathrm{L}^{-1}$ (Table 2). The most common correlations found in these surveys are that $\mathrm{NO}_{3}{ }^{-}$concentrations tend to decrease with well-depth, and that the most frequently contaminated well types have a shallow bored or dug construction (Murphy, 1992; Ervin and Lusch, 1992). However, Sievers and Fulhage (1992a,b) found that $\mathrm{NO}_{3}^{-}$concentration was not significantly correlated with the depth of wells. Areas with sandy soils have shown a considerably greater percentage of contaminated wells (Baker et al., 1989). The application of fertilizer or manure has also been found to correlate with higher nitrate concentrations in the wells (Murphy, 1992; Sievers and Fulhage, 1992a,b).

Information on bacterial contamination for jurisdictions outside of Ontario is sparce. The evidence suggests that the frequency of contamination is generally greater than for either nitrate or pesticides (Table 2).

The frequency of detection of pesticides in wells has generally been between 10 and $25 \%$ (Table 2). In the National Pesticide Survey carried out in the U.S.A., pesticides were discovered in groundwater much less frequently than nitrate (U.S.A.E.P.A., 1992). Dimethyltetrachloroterephthalate (DCPA) metabolites $(2.5 \%$ of sites) and atrazine $(0.7 \%)$ were the most frequently encountered pesticides.

Despite the widespread use of gasoline as a fuel, derivative compounds have rarely been detected in groundwater (Hadley and Armstrong, 1991). However, Rush and Metzger (1991) estimated that $20 \%$ of approximately 40,000 underground storage tanks are leaking in Canada, which could mean 6000 to 12,000 leaking tanks in Ontario. There is no survey information to identify whether it poses a problem for water quality in rural areas, especially from on-farm 
storage, which is usually in above-ground tanks.

\section{Materials and Methods}

\subsection{Well survey design}

The Province of Ontario is often subdivided physiographically into Northern (N.Ont.) and Southern (S.Ont.) Ontario, with the boundary set approximately between the Precambrian Shield and the unconsolidated glacial deposits that form the surficial sediments over the majority of the southern part of the Province. The majority of the bedrock underlying S.Ont. is Paleozoic carbonate or shale. In some areas, groundwater supplies are drawn from these bedrock units although most rural wells are completed in the glacial overburden sediments. Surficial soils throughout the Province are highly variable and reflect the parent glacial deposits. In S.Ont., farms are situated on sediments ranging from continuous sand and gravel deposits in the south, to thick clayey tills in the west, but the majority are located in areas with complex surficial soils.

The nature of agricultural activity throughout the Province is diverse, ranging from livestock operations to cash-crops and orchards. Superimposing these different land-use practices on the variable soil conditions results in a wide spectrum of site-specific conditions. As such, the selection of a representative subset of wells within the rural well network requires the development of site selection criteria that will minimize sample population bias and will incorporate the most common conditions encountered across the province. The criteria adopted for the survey are explained below.

Within the practical constraints of the survey, it was considered that a total of between 1000 and 1500 wells could realistically be included in the study. Site selection criteria differed 
between N.Ont. and S.Ont. as a result of the distinct physiographic conditions in each area. The selection of survey sites in Southern Ontario will be considered first.

The initial criterion involved specifying sampling density in a given region according to the extent of agricultural activity at the township scale. Townships were identified where at least $50 \%$ of the total land area was being used for agricultural purposes. Of the 364 townships considered in S.Ont., 222 fell into this category. Within each of these townships four wells were to be selected. The next criterion was to select farms that reflected the dominant agricultural land use within the township. Farm enterprises were identified from the Agricultural Resource Inventory (ARI), developed by the Ontario Ministry of Agriculture and Food (OMAF, 1988). Three of the four wells would be on farms with practices typical of the most common land use within that township. The fourth well would be sited on a farm with a contrasting land use. For example, if the most common land use was cash cropping, the fourth farm selected would be a typical animal enterprise in the township. The final criterion was to select from farms located on the dominant and principal-secondary soil type in the township according to the county soils maps of Ontario. The level of detail incorporated into the maps varied from county to county, but were considered to provide information for polygons no larger than 25 ha. Variability within the polygons was also recognised. This resulted in a potential group of 888 well sites. In each of the 142 townships where agricultural activity occupied less than $50 \%$ of the land area, one (sometimes two) well sites were selected in areas covered by the dominant soil type. This resulted in an additional 161 sites.

In N.Ont., little agricultural land use information was available, and data on the distribution of soil types was also limited. Sites were chosen where at least three farm enterprises 
existed in close proximity to one another. In the 275 townships identified in the agriculturally developed areas of N.Ont., a total of 108 sampling sites were selected.

Field Inspectors of The Ontario Soil and Crop Improvement Association (OSCIA) were given township maps with potential sampling sites marked. Each inspector made the final selection of wells within each township, taking into account what was known about the water well at potential sites, and the willingness of the farmer to participate in the survey. A total of 1157 water well sampling sites were finally chosen using this procedure. In addition, samples were collected from domestic water wells at 135 farms where multilevel monitoring wells were installed (see Rudolph et al., 1998). A complete network of 1292 farmstead domestic water wells was thus selected as a sample population of an estimated 500,000 wells in Ontario, and the final form of the study thus conformed to a stratified random survey. Samples from each well were analysed for $\mathrm{NO}_{3}^{-}$, pesticides, and bacterial indicator species.

A subset of 160 farm wells included in the initial sample population was selected for investigation of the presence of petroleum derivatives. Farm sites with a wide variety of soil types and land-use practices were selected. A total of 136 sites was chosen where a fuel storage tank had been in position for at least one yr, and was located within $60 \mathrm{~m}$ of the water well. The remaining 24 sites were selected on farms where there was no petroleum storage tank.

\subsection{Sampling and chemical analysis protocols}

The domestic wells were first sampled in winter between November 1991 to January 1992. The second sampling of the same well network was carried out in summer between June and July 1992. At each farm included in the survey, a detailed questionnaire was completed with 
the assistance of the farmer on both occasions the well water was sampled. The questionnaire sought information on cropping practice, livestock operations, and locations of septic fields, feedlots, manure stores, and milk-house waste disposal systems. Questions related to well construction, maintenance schedules and historical quality were also included in the questionnaire. OSCIA Field Inspectors collected unfiltered samples from the tap closest to the well head (commonly the kitchen tap) before the water had passed through any water treatment device. Aerators and other faucet attachments were removed, and taps were opened for at least five minutes to permit purging of the system prior to sampling.

Samples for analysis of pesticide content were collected in 1-L amber glass bottles. Samples for analysis of nitrate were collected in $20-\mathrm{mL}$ polyethylene vials, and samples for bacteriological analysis were collected in 250-mL plastic, sterile, screw-capped bottles that contained sodium thiosulphate to neutralize oxidants formed by any chlorine added to a well. Samples for analysis of petroleum derivatives were collected only during the first sampling event (winter 1991-1992). In this case, water was collected in 40-mL glass vials. All samples were stored in the dark at cool temperatures for transport to the various analytical facilities.

The bacteriological samples were analysed at local Ministry of Health laboratories on the day after collection following standard membrane filtration techniques (Clesceri et al., 1989) for detection of coliforms, faecal coliforms and faecal streptococci. Sub-samples $(50 \mathrm{~mL})$ were drawn through a cellulose-acetate membrane filter $(0.45 \mu \mathrm{m}$ pore size $)$. The second filter was sometimes incubated on a modified agar plate to detect Escherichia coli, faecal streptococcus or enterococcus species.

Nitrate concentration was measured spectrophotometrically after reduction to nitrite in a 
copper-cadmium column using a Technicon Random Access Automated Chemistry System TRAACS-800 (Alpha-Laval. AB. Stockholm, Sweden) at the Analytical Services Laboratory, University of Guelph. The pesticide analyses were conducted at the Agricultural and Food Laboratory Services-Pesticide Laboratory of the Ontario Ministry of Agriculture, Food and Rural Affairs, Guelph. The pesticides alachlor, atrazine, cyanazine, metribuzin, and metolachlor were chosen for study because of their extensive past or present use in the Province and their persistence in the environment as indicated by the frequency of detection in previous surveys. A metabolite, deethylatrazine, was also investigated because in Ontario the maximum acceptable concentration (MAC) in drinking water is the total of that of atrazine and this metabolite. Each sample was sub-sampled and analysed for the occurrence of atrazine by an enzyme linked imunoassay system (Agri-Diagnostics Associates, Moorestown, New Jersey, U.S.A.), and for alachlor, metolachlor, deethylatrazine, metribuzin and cyanazine by solid phase extraction followed by gas chromatography. Positive detections of all pesticides were confirmed on the remaining sample by chloroform liquid-liquid extraction followed by gas-liquid chromatography. Detection limits $(\mu \mathrm{g}$ $\left.\mathrm{L}^{-1}\right)$ were: alachlor, 0.2; atrazine, 0.05; cyanazine, 0.2; metribuzin, 0.05; metolachlor, 0.2; deethylatrazine, 0.1 .

Samples collected for investigation of contamination with petroleum derivatives, including benzene, toluene, ethylbenzene, and xylene (BTEX) were transported to the University of Waterloo for analysis using a pentane liquid-liquid microextraction/gas chromatographic technique. Holding times were one week. Samples and aqueous standards were extracted with pentane. The internal standard, m-fluorotoluene was used. A $4 \mu \mathrm{L}$ aliquot of the pentane phase was injected into an isothermal gas chromatograph equipped with a split injection port, a fused- 
quartz capillary column with a $0.25 \mu \mathrm{m}$ bonded CARBOWAX 20M stationary phase, and a flame ionization detector. The minimum detection limits for each compound were $\left(\mu \mathrm{g} \mathrm{L}^{-1}\right)$ : benzene, 1.84; ethyl benzene, 1.17; toluene, 1.44; p-xylene, 1.09; m-xylene, 1.18; and o-xylene, 1.52.

The information from the questionnaires together with the biological and chemical data from the various analytical laboratories, were compiled in a single data base designed to be GIS compatible.

\subsection{Survey interpretation and statistical analysis}

To evaluate the general level of contamination in water well samples collected in the survey, observed concentrations were compared with the Ontario Drinking Water Objectives as applied to private well supplies (MOE, 1992) (Table 3). Wells were deemed contaminated if one or more of the target contaminants were present in excess of the maximum acceptable concentration (MAC). The MAC of total coliform bacteria in private drinking water supplies was revised by the Ontario Ministry of Health (MOH), in October 1992, from 10 to 5 colonies per 100 $\mathrm{mL}$. Although this change took place after the sampling was completed, results were analysed relative to the new objective. For several groups of bacteria, no current objective was available, so values suggested by the MOH (M. Brodsky, personal communication, July 1992) were adopted. These limits are somewhat arbitrary, as they have not been developed on the basis of epidemiological studies to evaluate the associated health risks. Also, the newer guideline value of 5 total coliform was based on what would normally be expected in water of good quality where there are no known sewage sources. The epidemiological basis for this value is also tenuous. Drinking water objectives for the selected pesticides (Table 3) were taken as the MAC or interim 
MAC (IMAC) given in Ontario Drinking Water Objectives (MOE, 1992).

The percentage of contaminated wells in a given category was determined arithmetically, and then a 95\% confidence interval (CI) was calculated for each percentage contamination value by assuming a binomial distribution. A difference between two values of percent wells contaminated was considered to be significant if the values \pm their $95 \%$ C.I. did not overlap each other. The impact of well construction, depth and age, and distance from point source contamination was studied by subjecting the results to logistic multiple regression analysis using the Genstat 5:2.2 statistical system (Genstat 5 Committee, 1987). The independent variables used in the model included well depth, distance from feedlots, distance from manure storage systems, and distance from septic fields. For this analysis, a value of one was assigned to the response (dependent variable) if the level of contamination exceeded the drinking water objective, or that atrazine or deethylatrazine was present in the water, otherwise it was assigned a value of zero. The USDA hydrological group classification of soils based on infiltration and groundwater transmission rates (USDA, Soil Conservation Service, 1972) was also included in the model development for nitrate.

\section{Results}

\subsection{General level of contamination in domestic water wells}

About $40 \%$ of the nearly 1300 wells tested contained one or more of the target contaminants above the maximum acceptable concentration (Table 4). Bacteria were the most widespread form of contamination with about $34 \%$ of wells having more than the maximum 
number of coliform bacteria (faecal coliforms, or E. coli, or total coliforms) permissible in drinking water. Some $14 \%$ of the wells contained $\mathrm{NO}_{3}{ }^{-} \mathrm{N}$ concentrations above the $10 \mathrm{mg} \mathrm{L}^{-1}$ limit and about $7 \%$ of the wells were contaminated both with bacteria and nitrate. Six wells contained pesticide residues above the interim maximum acceptable concentration (IMAC). One contained alachlor, one contained metolachlor, and the remainder contained more than $5 \mu \mathrm{g} \mathrm{L}^{-1}$ of atrazine, or the total concentration of atrazine plus deethylatrazine exceeded $5 \mu \mathrm{g} \mathrm{L} \mathrm{L}^{-1}$. Records showed that a spill caused the one well to be contaminated with metolachlor. None of the wells tested contained detectable petroleum derivatives.

Almost $68 \%$ of wells tested in summer met the MAC for total coliform bacteria $(\leq 5)$ (Fig. 1). Of the wells having more than 10 coliform colonies per $100 \mathrm{~mL}$, about $40 \%$ had 80 or more. Seventy-five per cent of wells contained no faecal coliforms, and a further $4 \%$ contained only 1 colony per $100 \mathrm{~mL}$. Approximately $85 \%$ of wells tested had less than $10 \mathrm{mg} \mathrm{NO}_{3}^{-}-\mathrm{N} \mathrm{L}^{-1}$, but $11 \%$ had $\mathrm{NO}_{3}^{-}-\mathrm{N}$ concentrations from $5-10 \mathrm{mg} \mathrm{L}^{-1}$.

There was a reasonable correlation between the $\mathrm{NO}_{3}{ }^{-} \mathrm{N}$ concentrations measured in the winter and summer (regression $r^{2}=0.66, p<0.001$ ), but the bacterial counts in the summer were not correlated with counts in the previous winter. The populations of wells contaminated with bacteria differed between the winter and summer, even though the total percentage of bacterialcontaminated wells were similar for the two occasions. Bacterial contamination was apparently subject to considerable seasonal variability, whereas $\mathrm{NO}_{3}{ }^{-}$contamination was more consistent.

Pesticides were detected in $7.4 \pm 1.53 \%$ of the 1175 wells in the winter, and in $11.5 \pm$ $1.86 \%$ of wells in the summer. In both winter and summer atrazine was the major contaminant species $(6.6 \pm 1.45 \%$ and $10.5 \pm 1.79 \%$ respectively $)$. 
The results for N.Ont. and S.Ont. showed some differences in the proportion of wells contaminated with bacteria, though not with $\mathrm{NO}_{3}{ }^{-}$-N. Pesticide detections also showed regional variation. The two parts of the Province did not differ significantly in the proportions of types or depths of wells, but most farms in N.Ont. carried livestock. In both parts, about $40 \%$ of wells tested exceeded the MAC for one of the target contaminants. In the winter, the proportion of wells contaminated with total coliforms ( $>5$ colonies per $100 \mathrm{~mL}$ ) was significantly greater ( $<<0.001)$ in S.Ont. $(31 \pm 2.8 \%)$ than in N.Ont. $(15 \pm 7.1 \%)$, but there was no regional difference in summer. Overall, the levels of contamination with bacteria and $\mathrm{NO}_{3}{ }^{-}$in both areas were similar. There was no difference between the two areas in the proportion of wells with a detectable concentration of pesticide for winter samples, but in the summer significantly more wells $(\mathrm{p}=0.05)$ contained atrazine and de-ethyl deethylatrazine in S.Ont. $(12.1 \pm 1.99 \%)$ than in N.Ont. $(5.1 \pm 4.45 \%)$.

\subsection{Impact of well characteristics}

The proportion of water wells containing $\mathrm{NO}_{3}{ }^{-}$or bacteria in excess of the appropriate maximum acceptable concentration was investigated as a function of the depth and type of water well construction together with the age of the well (Fig. 2). The logistic regression equations depicted in Fig. 2 are given in the Appendix (Tables A1 \& A2). Logistic regression analysis showed that for contamination with bacteria and $\mathrm{NO}_{3}{ }^{-}$, well depth was particularly important, and the combination of well type and depth accounted for the largest reduction in the deviance. Sandpoints and dug or bored wells showed a similar distribution of $\mathrm{NO}_{3}{ }^{-}$contamination with depth, and both were more frequently contaminated than were drilled wells. Compared with dug 
or bored wells and sandpoint wells, the intercept of the regression for drilled wells was less but the slope was not significantly different (Fig. 2a). There were significant differences among the three types of well construction in the distribution of contamination by bacteria with depth (Fig. 2b). The incidence of bacterial contamination in sandpoints showed no significant variation with depth, whereas that for dug or for drilled wells decreased with the depth of the well.

In addition to type of well construction and well depth, age was the only additional parameter that had a significant effect on reducing the deviance in the contamination. There was a statistically significant increase in both the concentration of $\mathrm{NO}_{3}{ }^{-}$and number of bacterial colonies with well age. The fitted relationships for the frequency of $\mathrm{NO}_{3}{ }^{-}$contamination in $\mathrm{dug}$ wells and sandpoints with well depth and age are shown in Fig. 2c. The effect of age decreased with depth, and at a depth of $30 \mathrm{~m}$ the frequency of contamination in wells 100 years old was only $5 \%$ greater than in wells 5 years old. The impact of age in drilled wells was generally small because of their depth (results not shown). For wells contaminated with bacteria, the effect of age for drilled wells was similar to that for dug wells (Fig. 2d), but effects were much less for sandpoints because of the small incidence of contamination (results not shown).

The presence of atrazine and its breakdown product deethylatrazine, depended on the type of well construction, depth, and age (Fig. 3a and 3b, Table A3). The form of the relationship was similar to that for nitrate contamination, but for the pesticides, the intercept was similar for sandpoint and drilled wells; the intercept for dug or bored wells being significantly greater than that for drilled wells.

\subsection{Influence of Soil Type}


Wells were located on a total of 154 different soil series ranging from coarse sands and gravelly soils to silty loams and clays. For most soil series the percentage of wells contaminated with coliform bacteria was greater than that for nitrate (results not shown). To simplify further analysis, each well location in Southern Ontario was classified according to its hydrologic soil group (USDA, Soil Conservation Service, 1972). In soils of Hydrologic Group A (permeable sands and gravels), about $27 \%$ of the wells were contaminated with nitrate (Fig. 4). This percentage decreased steadily with hydrologic soil group to around 7\% in the Hydrologic Group D soils (clays). Bacterial contamination was greatest (cir. 35\%) in Hydrologic Group B soils, which are moderately permeable, but wells in coarser and finer textured soils were contaminated at about the same frequency (cir. 30\%), while wells in Hydrologic Group A were least contaminated.

As no point sources investigated contributed significantly to the logistic model for $\mathrm{NO}_{3}^{-}$ contamination, a final model including the type of well construction, depth, age and soil hydrologic group was developed (Table A4). Sandpoint and dug or bored wells were fitted by the same parameters, and the level of contamination in these wells was consistently greater than that in drilled wells (Fig 5). Contamination of wells in soils of Hydrologic groups A and B could be fitted by the same model parameters in dug or bored wells and sand points, and also in drilled wells (Fig. 5). The results showed that for dug and sand-point wells there was no significant relationship between $\mathrm{NO}_{3}{ }^{-}$contamination and well depth for the coarser textured soils, but there was a rapid decrease in contamination with depth in finer textured soils. The drilled wells showed the largest decrease in contamination with depth in the coarse textured soils, because the proportion of contaminated drilled wells was very small in finer textured soils. 


\subsection{Point source contamination of farm wells}

The major potential point source for $\mathrm{NO}_{3}{ }^{-}$and bacterial contamination on most farms was the septic or sewage disposal system. No significant effects were found on the level of contamination with nitrate or bacteria due to the distance from the well head to the weeping bed or to the septic tank. On livestock farms, the distance from the well-head to the feedlot or exercise yard was also investigated. No correlation was significantly greater than 0 at $p \leq 0.05$ for nitrate, but there was a significant decrease in contamination by coliform bacteria with increasing separation of the well from the feedlot (Table 5). The relationship was characterized by common slope parameters, but the intercept was significantly greater for dug or bored wells than for drilled wells.

\subsection{Influence of agricultural land management}

Information from the questionnaires was used in conjunction with The `Agricultural Resource Inventory (ARI) - land-use system' devised by the Ontario Ministry of Agriculture, Food and Rural Affairs to define the land-use class (cropping system) for each farm. The majority of the well sites fitted into just 15 different land-uses. Questionnaires also indicated manure and fertilizer application rates.

No land-use class was associated with significantly more $\mathrm{NO}_{3}{ }^{-}$-contaminated wells than any other (Fig 6). However, the average level of contamination was greatest in some of the minor land-use systems such as orchards and tobacco, although the population size for any given landuse practice was small.

There was no obvious correlation between a particular land-use and the occurrence of 
bacterial contamination in the groundwater (results not shown).

\section{Discussion}

The results from our stratified random survey showed that almost $40 \%$ of the tested wells in both the winter and summer sampling episodes did not meet provincial standards for drinking water. This represents a considerable proportion of the active drinking water wells in rural Ontario and clearly indicates a need for action to address the problem. The proportion of wells contaminated with nitrate was consistent with other, more limited, surveys conducted within the province of Ontario (Table 1), and in comparable regions of intensive agriculture in North America (Table 2). Surveys of water wells to assess regional groundwater quality have frequently been subjective and influenced strongly by biases incorporated into the structure of the given survey. Commonly such biases have been associated with the site selection process, and are understandable considering that the nature of a survey forces the selection of only a small subset of an existing network of wells. If a degree of randomness can be incorporated into this selection process or the biases involved in the survey are understood and can be accounted for, it is possible to develop general observations and conclusions from survey data. Based on the current information, it would appear that in regions of intensive agriculture some 10-20\% of wells exceed standards for $\mathrm{NO}_{3}{ }^{-} \mathrm{N}$ and a higher frequency (20-30\%) contain levels of bacteria above drinking water standards. In most cases, contamination from pesticides is relatively infrequent. This study has highlighted the widespread nature of groundwater contamination and its significance in a variety of different agricultural environments.

The frequency of wells contaminated with $\mathrm{NO}_{3}{ }^{-}-\mathrm{N}$ observed in 1992 showed no significant 
change from a regional-scale survey conducted in Ontario in the early 1950's (Johnson, 1955), although the frequency of wells with E. coli has increased significantly. Although farming practices have developed considerably in the intervening years, the influence of agricultural activity on rural groundwater quality has remained fairly constant with respect to $\mathrm{NO}_{3}{ }^{-} \mathrm{N}$ contamination. The greater specialization of agricultural enterprises has resulted in a spatial separation of the farms producing feed from those utilizing it in animal production (Keddie and Mage, 1985), but this does not appear to have had an impact on the frequency of ground-water contamination. One factor that might have influenced the incidence of bacteriological contamination has been the development of liquid manure management systems, which were not introduced into Ontario until the late 1950's.

The occurrence of groundwater contamination was directly related to the type, depth and age of the water well. Dug and bored wells or shallow sandpoints were more frequently contaminated than drilled wells regardless of depth, although the occurrence of contamination tended to decrease with depth for all well types. Similar results have been found for nitrate contamination (Murphy, 1992; Ervin and Lusch, 1992), but our results differ from those of Fleming (1992) who found that bacteriological contamination was not a function of well depth or age. The increased probability of finding contamination in older wells, particularly for the shallower wells, may be partly due to maintenance problems. On the basis of these observations, drilled and cased wells completed as deep as the local hydrogeologic conditions permit, would appear to be preferable for both new and replacement wells.

From analysis of both the winter and summer sampling episodes, no seasonal trends are evident with respect to $\mathrm{NO}_{3}{ }^{-}$contamination. However, for bacteriological contamination the 
subset of wells that were contaminated in the summer was significantly different from the winter subset, although the number of wells exceeding the drinking water objective was similar. The bacteria therefore appeared to be susceptible to seasonal changes which may be influenced by soil temperature (Thelin and Gifford, 1983), manure application schedules (Chandler et al., 1981), variations in surface hydrology (Abu-Ashour et al., 1994), and biological activity related to the growth cycles of the crops (Bell, 1976; Bell and Bole, 1976).

The only correlation between point sources of contamination on the farm and contamination in the water wells was for bacteria contamination and separation distance of the well from a feedlot or animal exercise yard.

Nitrate in drinking water wells was more influenced by the distributed source of contamination associated with the adjacent cropped fields than by point sources. There was no significant influence of cropping practice on the frequency of groundwater contamination.

Considering the small size of the data set associated with each land-use practice (Fig.6), this scale of survey was not sufficient to identify the influence of cropping practices on groundwater quality.

\section{Conclusions}

The results of the survey indicated that the level of contamination with $\mathrm{NO}_{3}{ }^{-}$, bacteria and pesticides in rural drinking water wells in Ontario was similar to that in other parts of North America. No wells were found to be contaminated with petroleum derivatives resulting from onfarm storage, suggesting that this is of minor concern. Contamination with $\mathrm{NO}_{3}{ }^{-}-\mathrm{N}$ showed no significant change over the past 40 years, but contamination with $E$. coli had almost doubled.

Evidence from this survey and others indicate the significance of distributed sources of 
contamination related to agricultural production.

\section{Acknowledgements}

We acknowledge the contribution of staff from the following federal and provincial organizations: Agriculture and Agri-Food Canada, the Ontario Soil and Crop Improvement Association, the Resources Management Branch and the Pesticide Residue Laboratory of the Ontario Ministry of Agriculture, Food and Rural Affairs, the Ontario Ministry of the Environment and Energy, the Ontario Ministry of Health, the Analytical Services Laboratory of the Department of Land Resource Science University of Guelph. We gratefully acknowledge the technical support of staff from the Centre for Groundwater Research, University of Waterloo. Funding for the project was provided under Federal-Provincial Government Agreements through Agriculture and Agri-Food Canada. Special thanks are accorded to the farm families whose participation contributed greatly to the success of the survey. Finally we gratefully acknowledge the support and encouragement given by Dr R. G. Kachanoski at all stages of this project. 


\section{References}

Abu-Ashour, J., Joy, D. M., Lee, H., Whitely, H. R., and Zelin, S. 1994. Transport of microorganisms through soil. Water, Air and Soil Pollution 75: 141-58.

Allen, M.C., Ecobichon, D.J., and Hicks, R.A. 1984. Well Water study, Carleton County. Health and Community Services, New Brunswick Dept. of Health, Frederiction, N.B.

Allen, M.C., Ecobichon, D.J., and Hicks, R.A. 1985. Well Water Study, Madawaska and Victoria Counties. Health and Community Services, New Brunswick Dept. of Health, Frederiction, N.B.

Baker, D., Wallrabenstein, L., Richards, R., and N. Creamer. 1989. Nitrate and pesticides in private wells of Ohio: a state atlas. Tiffin, Ohio: The Water Quality Laboratory, Heidelberg College.

Bauder, J. W., White, B. A., and Inskeep, W. P. 1991. Montana extension initiative focuses on private well quality. Journal of Soil and Water Conservation 46: 69-74.

Bell, R. G. 1976. Persistence of fecal coliform indicator bacteria on alfalfa irrigated with municipal sewage lagoon effluent. Journal of Environmental Quality 5: 39-42.

Bell, R. G., and Bole, J. B. 1976. Elimination of fecal coliform bacteria from reed canarygrass irrigated with municipal sewage lagoon effluent. Journal of Environmental Quality 5: 41718.

Brown, D. 1981. A water quality survey of wells in an agricultural area of Sydenham Township, Grey County. Ontario Ministry of the Environment, Southwestern Region, Technical Support Section.

CAESA Water Quality Committee. 1995. CAESA water quality program - An integrated 
approach. Canada-Alberta environmentally sustainable agriculture agreement.

Chandler, D. S., Farran, I., and Craven, J. A. 1981. Persistence and distribution of pollution indicator bacteria on land used for disposal of piggery effluent. Applied and Environmental Microbiology 42: 453-60.

Clesceri, L. S., Greenberg, A. E., and Trussel, R. R. 1989. Standard Methods for the Examination of Water and Wastewater. Seventeenth ed., 9-83 - 9-91. Washington, D.C.: American Public Health Association.

Comstock, J. 1996. Generic State Management Plan for Pesticides and Groundwater. Montpelier, Vermont: Vermont Department of Agriculture, Food and Markets.

Craun, G. 1984. Health aspects of ground water pollution. In good question. ed G. Bitton, and C. Gerba, 135-80. New York: Wiley-Interscience.

Ecobichon, D. J., Hicks, R., Allen, M. C., and Albert, R. 1990. Ground water contamination in rural New Brunswick. Environmental Health Review Fall 1990: 75-79.

Emergency Response and Coordination Group. 1996. Nine State Midwestern Well Survey (1994). Atlanta, Georgia, USA.: National Centre for Environmental Health, Centre for Disease Control.

Ervin, J. L., and Lusch, D.P. 1992. Selection and analysis of sites highly vulnerable to groundwater contamination in Southwestern Michigan. East Lansing, Michigan: Institute of Water Research, Michigan State University.

Exner, M. E., and Spalding, R. F. 1985. Ground-water contamination and well construction in southeast Nebraska. Ground Water 23: 26-34.

Fleming, R. J. 1992. Rural well water survey, Huron County - 1991, Final report to the Ontario 
Ministry of Agriculture and Food. Centralia College of Agricultural Technology, Huron Park, ON, Canada.

Frank, R., Braun, H., Clegg, S., Ripley, B., and Johnson, R. 1990. Survey of farm wells for pesticides, Ontario, Canada, 1986 and 1987. Bulletin of Environmental Contamination and Toxicology 44: 410-419.

Frank, R., Chapman, N., and Johnson, R. 1991. Survey of Farm Wells for Nutrients and Minerals, Ontario, Canada, 1986 and 1987. Bull. Environ. Contam. Toxicol. 47: 146-51.

Frank, R., Clegg, S., Ripley, B., and Braun, H. 1987a. Investigations of pesticide contaminations in rural wells, 1969-84, Ontario, Canada. Archives of Environmental Contamination and Toxicology 16: 9-22.

Frank, R., Ripley, B., Braun, H., Clegg, S., Johnson, R., and O'Neill, T. 1987b. Survey of farm wells for pesticides residues, Southern Ontario, Canada, 1981-1982, 1984. Archives of Environmental Contamination and Toxicology 16: 1-8.

Genstat 5 Committee. 1987. Genstat 5 Reference Manual. Oxford: Clarendon Press.

Gosselin, D.C., Headrick, J., Tremblay, R., Chen, X., and Summerside, S. 1997. Domestic water well quality in rural Nebraska: focus on nitrate-nitrogen, pesticides, and coliform bacteria. Ground Water Monitoring and Remediation 17(2):77-87.

Government of Nova Scotia. 1990. Nova Scotia Farm well water quality assurance study, Phase I - Final report. Province of Nova Scotia.

Hadley, P., and Armstrong, R. 1991. Where's the benzene - examining California ground-water quality surveys. Ground Water 29:35-40.

Hallberg, G., Kross, B., Libra, R., Burmeister, L., Weih, L., Lynch, C., Bruner, D., Lewis, M., 
Cherryholmes, K., Johnson, J., and Culp, M. 1990. The Iowa state-wide rural well-water survey design report: a systematic sample of domestic drinking water quality. Technical Information Series 17. Ames, Iowa: Iowa Department of Natural Resources.

Holden, L., Graham, J., Whitmore, R., Alexander, J., Pratt, R., Liddle, S., and Piper, L. 1992. Results of the National Alachlor Well Water Survey. Environmental Science and Technology 26: 935-43.

Howard, K., and Falck, H. 1986. Interrelationships of land use, soil conditions and groundwater contamination near Lindsay, Ontario. Canadian Water Resources Journal 11: 111-25.

Jennings, G.D., Sneed, R.E., Huffman, R.L., Humenik, F.J., and Smolen, M.D. 1991. Nitrate and pesticide occurrence in North Carolina wells. ASAE Paper 912107. Am. Soc. Agr. Eng., St. Joseph, MI.

Johnston, R. A. 1955. The incidence of nitrates in rural Ontario well waters. Canadian Journal of Public Health 46: 30-34.

Keddie, P. D., and Mage, J.A. 1985. Southern Ontario atlas of agriculture: Contemporary patterns and recent changes. Occasional Papers in Geography, 7. Guelph, Ontario: University of Guelph.

Keeney, D. R. 1989. Sources of nitrate to groundwater. In: Nitrogen management and ground water protection. ed R.F. Follett, pp. 23-33. New York, NY: Elsevier Science.

Kross, B. C., Selim, M. I., Hallberg, G. R., Bruner, D. R., and Cherryholmes, K. 1992. Pesticide contamination of private well water, a growing rural health concern. Environmental International 18: 231-41.

Lee-Han, H., and Hatton, B. 1991. Survey of bacteriological and nitrate contamination of private 
well water. Regional Municipality of Waterloo, Waterloo, Ontario.

Mackay, D., and Smith, L. 1990. Agricultural chemicals in groundwater: monitoring and management in California. Journal of Soil and Water Conservation 45: 253-55.

MOE. 1992. Ontario's drinking water objectives. Environment Information, summer. Ontario Ministry of the Environment, Toronto, Ontario.

Mueller, D. K., Hamilton, P. A., Helsel, D. R., Hitt, K. J., and Ruddy, B. C. 1995. Nutrients in ground water and surface water of the United States - an analysis of data through 1992. Water Resources Investigations Report 95-4031 U.S. Geological Survey. Denver, Colorado, U.S.A.

Murphy, E. 1992. Nitrate in drinking water wells in Burlington and Mercer Counties, New Jersey. Journal of Soil and Water Conservation 47: 183-87.

Novakovic, B. 1985. Influence of agricultural land use on nitrate content in the shallow bedrock. Southwestern Region Technical Support Section Monthly Newsletter prepared by the Ontario Ministry of the Environment (MOE) Vol. 10.

Ontario Ministry of Agriculture and Food (OMAF). 1988. Agricultural resource inventory, prepared by the Soil and Water Management Branch, Ontario Ministry of Agriculture and Food, Toronto, Ontario.

Perth District Health Unit. 1994. Perth County rural water quality survey, 1991/92. Perth County, ON, Canada.

Quebec Ministry of the Environment. 1994. Contamination du milieu aquatique et des eaux souterraines par les pesticides au Quebec. Direction du milieu agricole et du controle des pesticides. Sainte-Foy, Quebec.: Gouvernement du Quebec. 
Richards, J.E., Milburn, P., MacLean, A.A., and DeMerchant, G.P. 1990. Intensive potato production effects on nitrate-n concentrations of rural New Brunswick well water. Canadian Agricultural Engineering 32:189-196.

Rudolph, D.L., Barry, D.A.J., and Goss, M.J. 1998. Contamination in Ontario farmstead domestic wells and its association with agriculture: 2. Results from multilevel monitoring well installations. Contaminant Hydrology (this issue).

Rush, R., and Metzger, K. 1991. Leaking storage tank costs could rival our federal deficit. Environmental Science and Engineering 4:38-41.

Sievers, D. M., and Fulhage, C. D. 1992a. Nitrate in rural wells of Missouri. American Society of Agricultural Engineers 35: 1633-37.

- 1992b. Survey of rural wells in Missouri for pesticides and nitrate. Ground Water Monitoring Review 12: 142-50.

Simard, G, and DesRosiers, R. 1979. Qualite des eaux souterraines du Quebec. Gouvernement du Quebec, Ministere des Rechesses Naturelles, Quebec.

Steichen, J., Koelliker, J. Grosh, D., Heiman, A., Yearout, R., and Robbins, V. 1988. Contamination of farmstead wells by pesticides, volatile organics, and inorganic chemicals in Kansas. Ground Water Monitoring Review 8(3):153-160.

Swinstock, B. R., Sharpe, W. E., and Robillard, P. D. 1993. A survey of lead, nitrate and radon contamination of private individual water systems in Pennsylvania. Journal of Environmental Health 55: 6-12.

Texas State Soil and Water Conservation Board. 1991. A comprehensive study of Texas watersheds and their impacts on water quality and water quantity. TSSWCB, Temple, 
TX.

Thelin, R., and Gifford, G. F. 1983. Fecal coliform release patterns from fecal material of cattle. Journal of Environmental Quality 12: 57-63.

Turco, R. and Konopka, A. 1988. Agricultural impact on groundwater quality, Part 1: Well study. West Lafayette, Indiana: Water Resources Research Center, Purdue University.

U.S.A.E.P.A. 1990. National Pesticide Survey: summary of results of EPA's national survey of pesticides in drinking water. United States Environmental Protection Agency, Washington, D.C.

U.S.A.E.P.A. 1992. National survey of pesticides in drinking water wells. Phase II results. USEPA Rep. 570/9-91-021. United States Environmental Protection Agency, Washington D.C..

U.S.D.A. Soil Conservation Service.1972. National Engineering Handbook. Hydrology Section 4. United States Department of Agriculture, Washington, D.C. 
Table 1. Previous studies of contamination of well water in Ontario

\begin{tabular}{|c|c|c|c|c|c|c|}
\hline \multirow{3}{*}{ Source } & \multirow{3}{*}{$\begin{array}{l}\text { Study } \\
\text { period }\end{array}$} & \multirow{3}{*}{$\begin{array}{l}\text { Number } \\
\text { of wells }\end{array}$} & \multicolumn{3}{|c|}{$\%$ of wells contaminated } & \multirow{3}{*}{$\begin{array}{l}\text { Pesticide } \\
\text { detections }\end{array}$} \\
\hline & & & \multicolumn{2}{|c|}{$\mathrm{NO}_{3}^{-}$} & \multirow{2}{*}{$\begin{array}{c}\text { Coliform bacteria } \\
\qquad \text { (faecal) } \\
>10(>0) \\
\text { colonies / } 100 \mathrm{~mL}\end{array}$} & \\
\hline & & & $\begin{array}{c}>10 \\
\mathrm{mg} \mathrm{N} \mathrm{L}^{-1}\end{array}$ & $\begin{array}{c}5-10 \\
m g ~ ~^{-1}\end{array}$ & & \\
\hline Johnston, 1955 & $1950-54$ & 484 & 13.8 & & $14.9 \dagger$ & \\
\hline Brown, 1981 & 1980 & 37 & 5 & 16 & $43(27) \ddagger$ & \\
\hline Novakovic, 1985 & $1984-85$ & 63 & 21 & 44 & - & \\
\hline Howard \& Falck, 1986 & c1985 & 49 & 5 & - & - & \\
\hline Frank et al, 1987a & $1979-84$ & 359 & - & - & - & 37 \\
\hline Frank et al, 1987b & 1981-84 & 102 & - & - & - & 14 \\
\hline Frank et al, 1990 & 1984 & 91 & - & - & - & 13 \\
\hline Frank et al, 1990 & 1986 & 103 & - & - & - & 10 \\
\hline Frank et al, 1991 & 1986 & 103 & 15 & - & - & \\
\hline Frank et al, 1990 & 1987 & 76 & - & - & - & 5.3 \\
\hline Frank et al, 1991 & 1987 & 76 & 7 & - & - & \\
\hline Lee-Han \& Hatton, 1991 & 1990 & 566 & 11.7 & 17.2 & 37 & \\
\hline Perth District Health Unit 1994 & 1991-92 & 142 & 7 & 3 & $44(10) \ddagger$ & \\
\hline Fleming, 1992 & 1991 & 301 & 15 & - & $34(26) \ddagger$ & $10 \S$ \\
\hline
\end{tabular}


Table 2a. Previous Canadian studies of contamination of well water outside of Ontario

\begin{tabular}{|c|c|c|c|c|c|c|}
\hline \multirow[t]{2}{*}{ Source } & \multirow[t]{2}{*}{ Year } & \multirow[t]{2}{*}{ Jurisdiction } & \multirow{2}{*}{$\begin{array}{l}\text { Number } \\
\text { of wells }\end{array}$} & \multicolumn{2}{|c|}{$\%$ of wells contaminated } & \multirow[b]{2}{*}{$\begin{array}{c}\text { Pesticide } \\
\text { (detections) }\end{array}$} \\
\hline & & & & $\begin{array}{c}\mathrm{NO}_{3}^{-} \\
>10 \mathrm{mg} \mathrm{N} \mathrm{L}^{-1}\end{array}$ & $\begin{array}{c}\text { Bacteria } \\
\text { (faecal coliforms) }\end{array}$ & \\
\hline \multirow[t]{2}{*}{ Richards et al.1990 } & 1973-76 & New & 47 & 20 & 37 & \\
\hline & 1988 & Brunswick & & & & \\
\hline Simard \& Des Rosiers, 1979 & 1975-78 & Quebec & 216 & 1.5 & $27(14)$ & \\
\hline \multirow[t]{2}{*}{ Allen et al. 1984} & 1984 & New & 300 & 18 & 33 & $(62)$ \\
\hline & & Brunswick & & & & \\
\hline \multirow[t]{2}{*}{ Allen et al. 1985} & 1985 & New & 300 & 22 & 45 & $(20)$ \\
\hline & & Brunswick & & & & \\
\hline \multirow[t]{2}{*}{ Ecobichon et al., 1990} & $1984-85$ & New & 285 & 14.6 & $21(34)$ & $(\mathrm{c} 16) \dagger$ \\
\hline & & Brunswick & & & & \\
\hline \multirow[t]{2}{*}{ Ecobichon et al., 1990} & $1985-86$ & New & 300 & 20.2 & $29(10)$ & $(\mathrm{c} 13)$ \\
\hline & & Brunswick & & & & \\
\hline Quebec Ministry of the & 1984-91 & Quebec & 245 & & & $24 \dagger$ \\
\hline \multicolumn{7}{|l|}{ Environment, 1994} \\
\hline Government of Nova Scotia, & 1989 & Nova & 98 & & 7 & $(32) \ddagger$ \\
\hline 1990 & & Scotia & 136 & 12 & & \\
\hline CAESA Water Quality & 1994 & Alberta & 420 & 3 & 68 & 0 \\
\hline Committee, 1995 & & & & & & \\
\hline
\end{tabular}

$\uparrow$ Data for aldicarb

$\ddagger$ Data for atrazine 
Table 2b. Previous studies of contamination of well water in the United States of America

\begin{tabular}{|c|c|c|c|c|c|c|}
\hline \multirow[t]{2}{*}{ Source } & \multirow[t]{2}{*}{ Year } & \multirow[t]{2}{*}{ Jurisdiction } & \multirow{2}{*}{$\begin{array}{l}\text { Number } \\
\text { of wells }\end{array}$} & \multicolumn{2}{|c|}{$\%$ of wells contaminated } & \multirow{2}{*}{$\begin{array}{l}\text { Pesticide } \\
\text { (detections) }\end{array}$} \\
\hline & & & & $\begin{array}{c}\mathrm{NO}_{3}^{-} \\
>10 \mathrm{mg} \mathrm{N} \mathrm{L}^{-1}\end{array}$ & Bacteria & \\
\hline TSSWCB, 1991 & $1971-90$ & Texas & 26,412 & 7.6 & & \\
\hline \multirow[t]{2}{*}{ Mackay \& Smith, 1990} & $1975-87$ & California & 38,144 & 10 & & \\
\hline & & & 10,929 & & & 21 \\
\hline Steichen et al., 1988 & $1985-86$ & Kansas & 103 & 28 & & 8 \\
\hline Mueller et al., 1995 & $1980-90$ & USA & 11,715 & $9(21) \dagger$ & & \\
\hline Exner \& Spalding, 1985 & $1981-82$ & Nebraska (SE) & 268 & 71 & $37 \ddagger$ & $28 \S$ \\
\hline Turco \& Konopka,1988 & $1987-88$ & Indiana & 47 & 9 & & 15 \\
\hline Sievers \& Fulhage, 1992a & $1987-89$ & Missouri & 201 & 22 & & 43 \\
\hline Sievers \& Fulhage, 1992b & $1987-89$ & Missouri & 226 & 19 & & \\
\hline Murphy, 1992 & 1988 & New Jersey & 343 & 6 & & \\
\hline Hallberg et al., 1990 & $1988-89$ & Iowa & 686 & 18 & & 14 \\
\hline Kross et al., 1992 & $1988-89$ & Iowa & 686 & & 45 & \\
\hline U.S.A.E.P.A., 1990 & $1988-90$ & U.S.A. & 1292 & 2.4 & & 4 \\
\hline Holden et al., 1992 & $1988-89$ & U.S.A. & 1430 & 5 & - & $11.7 \S$ \\
\hline \multirow[t]{2}{*}{ Baker, 1989} & & Ohio & 16,166 & 2.9 & & \\
\hline & & & 610 & & & $9 \S$ \\
\hline \multirow[t]{2}{*}{ Bauder et al., 1991} & $1989-90$ & Montana & 557 & 6 & & 7 \\
\hline & & & 692 & 6 & & 6 \\
\hline Jennings et al., 1991 & 1989 & N. Carolina & 9026 & 3.2 & & \\
\hline Swinstock et al., 1993 & $1989-92$ & Pennsylvania & 1595 & 9 & & 6 \\
\hline Ervin \& Lusch, 1992 & 1990 & Michigan & 121 & 21 & & 20 \\
\hline Ervin \& Lusch, 1992 & 1990 & Michigan & 879 & 12 & & \\
\hline Gosselin et al., 1997 & 1994-95 & Nebraska & 1808 & 19 & 15 & $4 \S$ \\
\hline E.R.C.G., 1996 & $1994-95$ & USA-mid west & 5530 & 14 & 41 & 25 \\
\hline \multirow[t]{2}{*}{ Comstock, 1996} & $1986-95$ & Vermont & 582 & 15 (corn) & & 10 \\
\hline & $1991-95$ & & 36 & 8 (fruit \& veg) & & 12 \\
\hline
\end{tabular}

$\dagger$ Data for agricultural areas

$\ddagger$ Data for faecal coliform

$\S$ Data for atrazine 
Table 3. Drinking water objectives used in Ontario for the contaminants investigated in this study.

\begin{tabular}{|c|c|}
\hline Contaminant & Ontario (MAC or IMAC) \\
\hline Pesticides & $\mu \mathrm{g} \mathrm{L}^{-1}$ \\
\hline Alachlor & 5 \\
\hline Metolachlor & 50 \\
\hline Atrazine & $5 \dagger$ \\
\hline Metribuzin & 80 \\
\hline \multirow[t]{2}{*}{ Cyanazine } & 10 \\
\hline & $\mathrm{mg} \mathrm{N} \mathrm{L}^{-1}$ \\
\hline$\underline{\text { Nitrate }}$ & 10 \\
\hline$\underline{\text { Bacteria }}$ & $\begin{array}{l}\text { Colony forming units } \\
\qquad(100 \mathrm{ml})^{-1} \ddagger\end{array}$ \\
\hline Total coliform & 5 \\
\hline Faecal coliform & 0 \\
\hline
\end{tabular}


Table 4. Comparison of the distribution of bacterial, nitrate and pesticide contamination of Ontario farm wells in both winter and summer.

\begin{tabular}{|c|c|c|c|}
\hline \multirow[t]{2}{*}{ Contaminant } & \multirow[t]{2}{*}{ Wells Tested } & \multicolumn{2}{|c|}{ Exceeds Objectives } \\
\hline & & Winter & Summer \\
\hline & no. & $\%$ & $\%$ \\
\hline \multicolumn{4}{|l|}{$\underline{\text { Bacteria }}$} \\
\hline Total coliform & 1208 & $30.0 \pm 2.6 \dagger$ & $32.2 \pm 2.7$ \\
\hline Faecal coliform & 598 & $19.7 \pm 3.3$ & $25.3 \pm 3.6^{*}$ \\
\hline E. coli $>0$ & 268 & $16.8 \pm 4.6$ & $24.3 \pm 5.2^{*}$ \\
\hline F. streptococcus $>0$ & 335 & $11.6 \pm 3.5$ & $24.2 \pm 4.7 * * *$ \\
\hline Enterococci $>0$ & 68 & $16.2 \pm 8.9$ & $45.6 \pm 12.1^{* * *}$ \\
\hline Total coliform or faecal coliform & 598 & $31.6 \pm 3.8$ & $36.5 \pm 3.9$ \\
\hline Tot. colif., E. coli or faecal colif. & 1208 & $33.1 \pm 2.7$ & $35.4 \pm 2.8$ \\
\hline$\underline{\text { Nitrate }}>10$ & 1212 & $12.8 \pm 1.9$ & $14.3 \pm 2.0$ \\
\hline Bacteria $\ddagger$ or nitrate & 1204 & $38.9 \pm 2.8$ & $42.6 \pm 2.9$ \\
\hline Bacteria \& nitrate & 1204 & $7.1 \pm 1.5$ & $7.2 \pm 1.5$ \\
\hline \multicolumn{4}{|l|}{$\underline{\text { Pesticides }}$ (common \& trade name) } \\
\hline Alachlor (Lasso) & 1175 & 0 & $0.09 \pm 0.17$ \\
\hline Metolachlor (Dual) & 1175 & $0.09 \pm 0.17$ & $0.09 \pm 0.17$ \\
\hline Atrazine (Aatrex) & 1175 & $0.17 \pm 0.24$ & $0.09 \pm 0.17$ \\
\hline Deethylatrazine & 1175 & 0 & $0.09 \pm 0.17$ \\
\hline Atrazine + deethylatrazine & 1175 & $0.17 \pm 0.24$ & $0.34 \pm 0.34$ \\
\hline Metribuzin (Sencor) & 1175 & 0 & 0.00 \\
\hline Cyanazine (Bladex) & 1175 & 0 & 0.00 \\
\hline \multicolumn{4}{|l|}{$\dagger \pm 95 \%$ confidence interval. } \\
\hline Bacteria include total coliforms, & al coliforms & coli. & \\
\hline
\end{tabular}


Table 5. Regression equations for predicting logit of proportion of wells with bacterial contamination, based on well type, well age (y), natural logarithm of well depth (m), and distance (m) to the farm feedlot (fldis).

\begin{tabular}{lc}
\hline \multicolumn{1}{c}{ Well Type } & Regression Equation \\
\hline Dug or bored wells & $1.43+0.98+0.0081 *$ age $-0.68 *$ Indepth $-0.0164 *$ fldis \\
& \\
Drilled wells or sandpoints & $1.43+0.0081 *$ age $-0.68 *$ Indepth $-0.0164 *$ fldis \\
\hline
\end{tabular}

Note: $\operatorname{logit}=\ln ($ proportion contaminated/(1-proportion contaminated $))$

Regression coefficients and their standard errors are:

Terms: Constants Age lndepth fldis

$$
\begin{array}{llll}
1.43 \pm 0.572 & 0.0081 \pm 0.00356 & -0.68 \pm 0.151 & -0.0164 \pm 0.00364 \\
0.98 \pm 0.253 & & &
\end{array}
$$




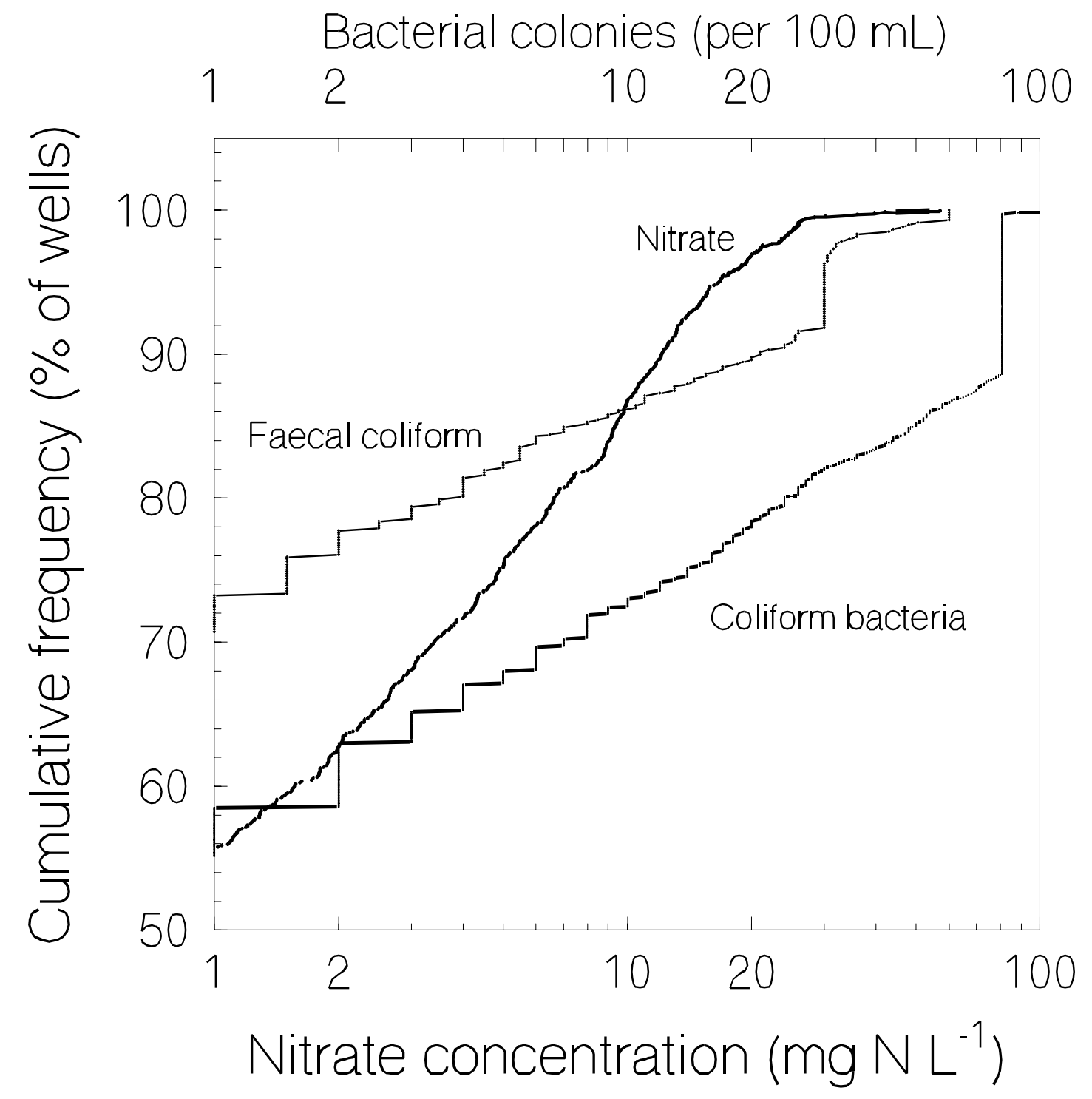

Figure 1 

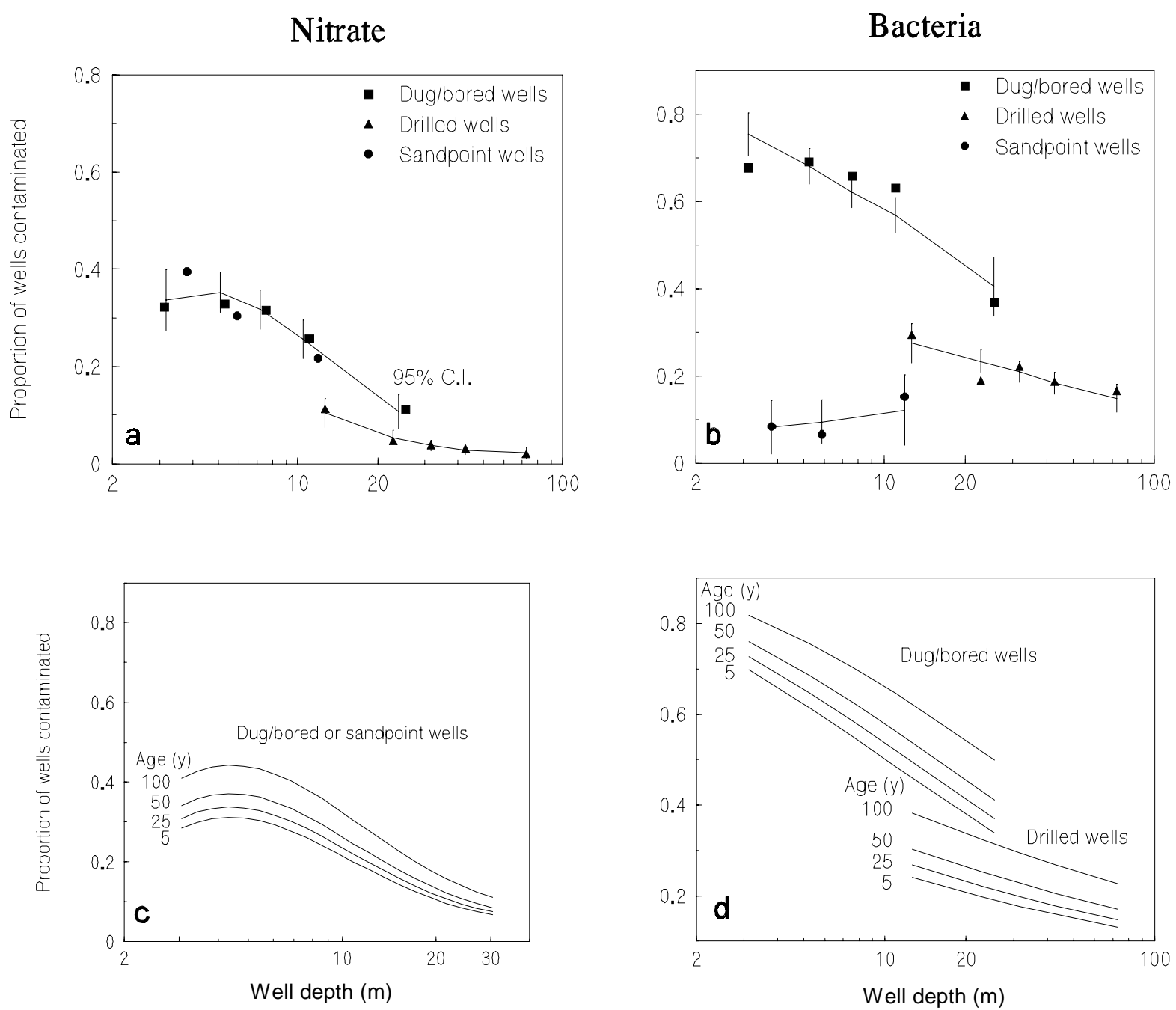

Figure 2 

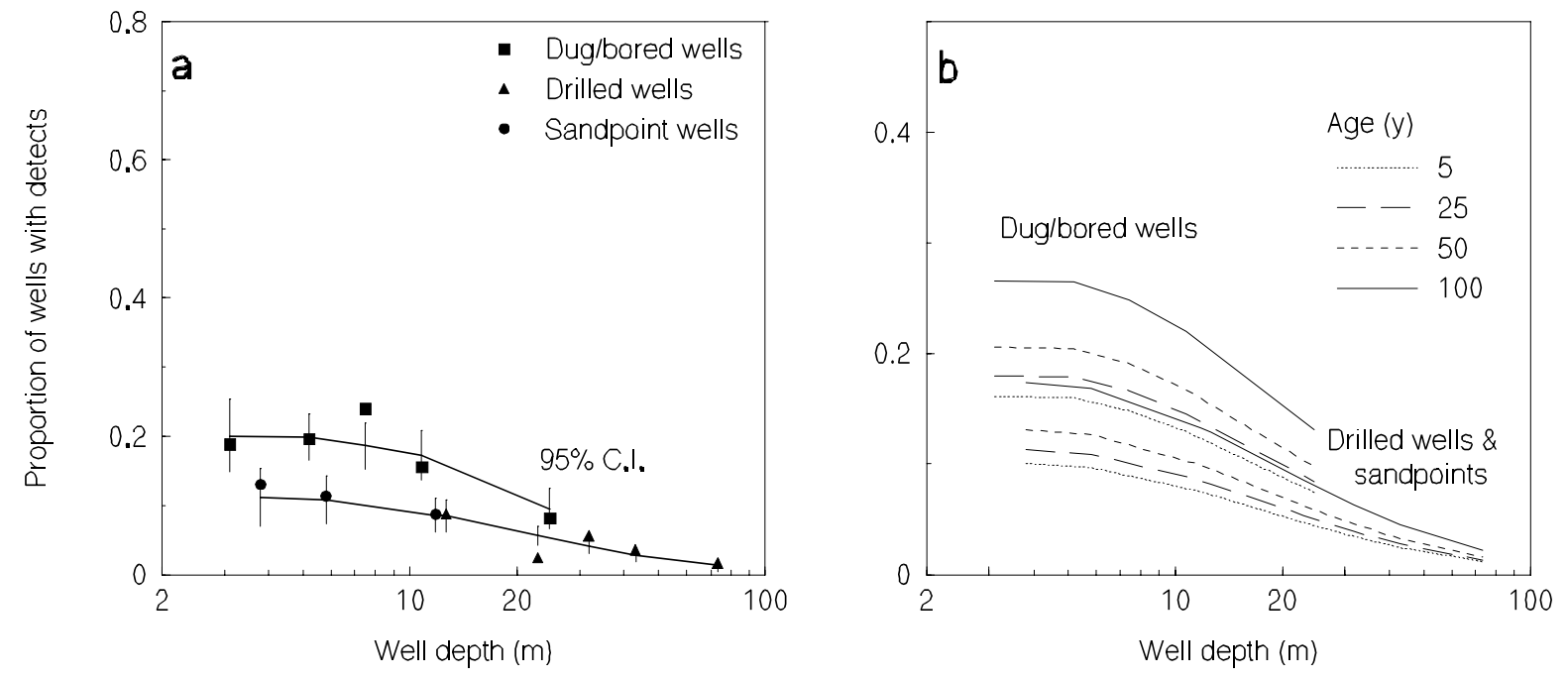

Figure 3 


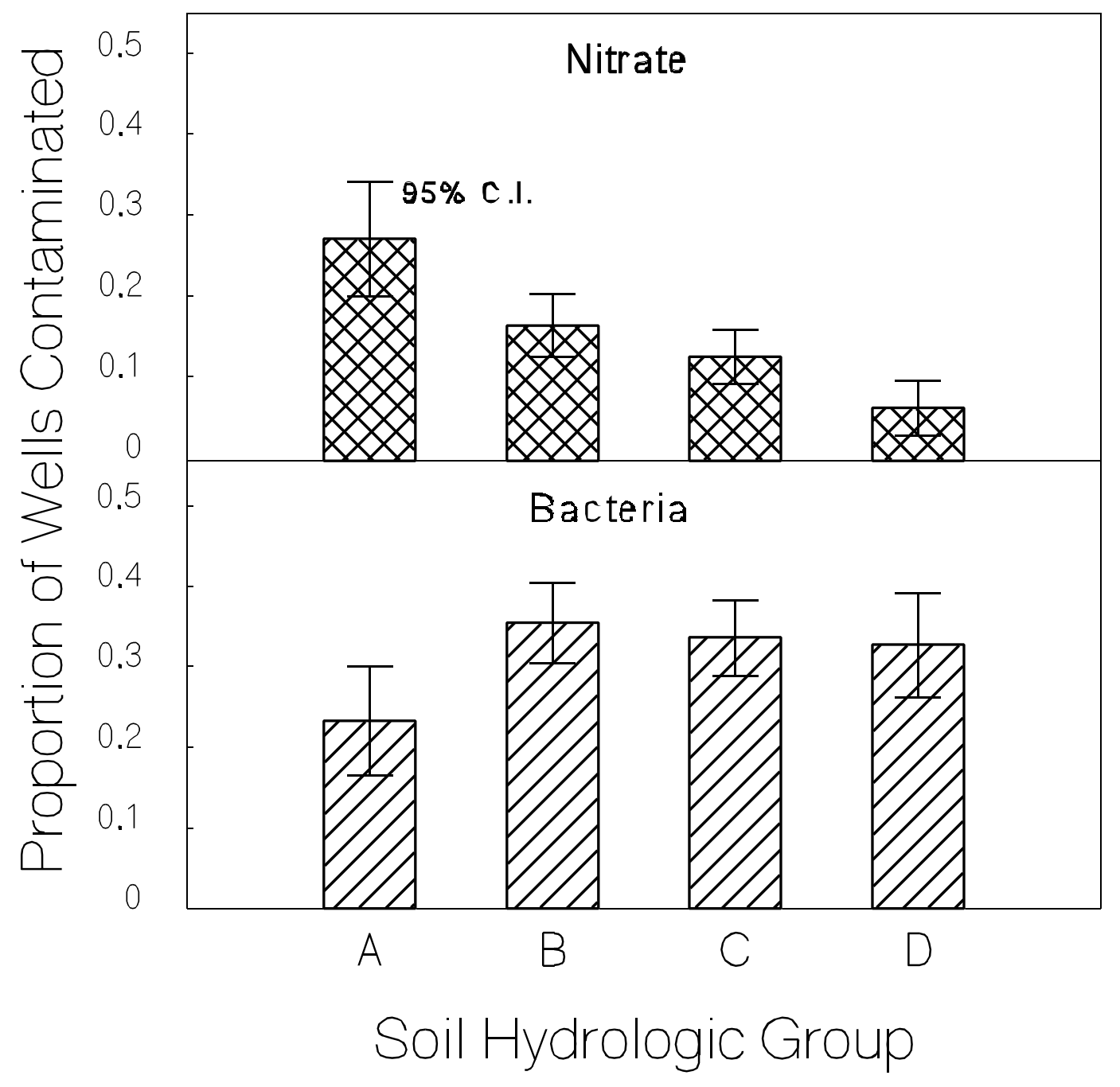

Figure 4 

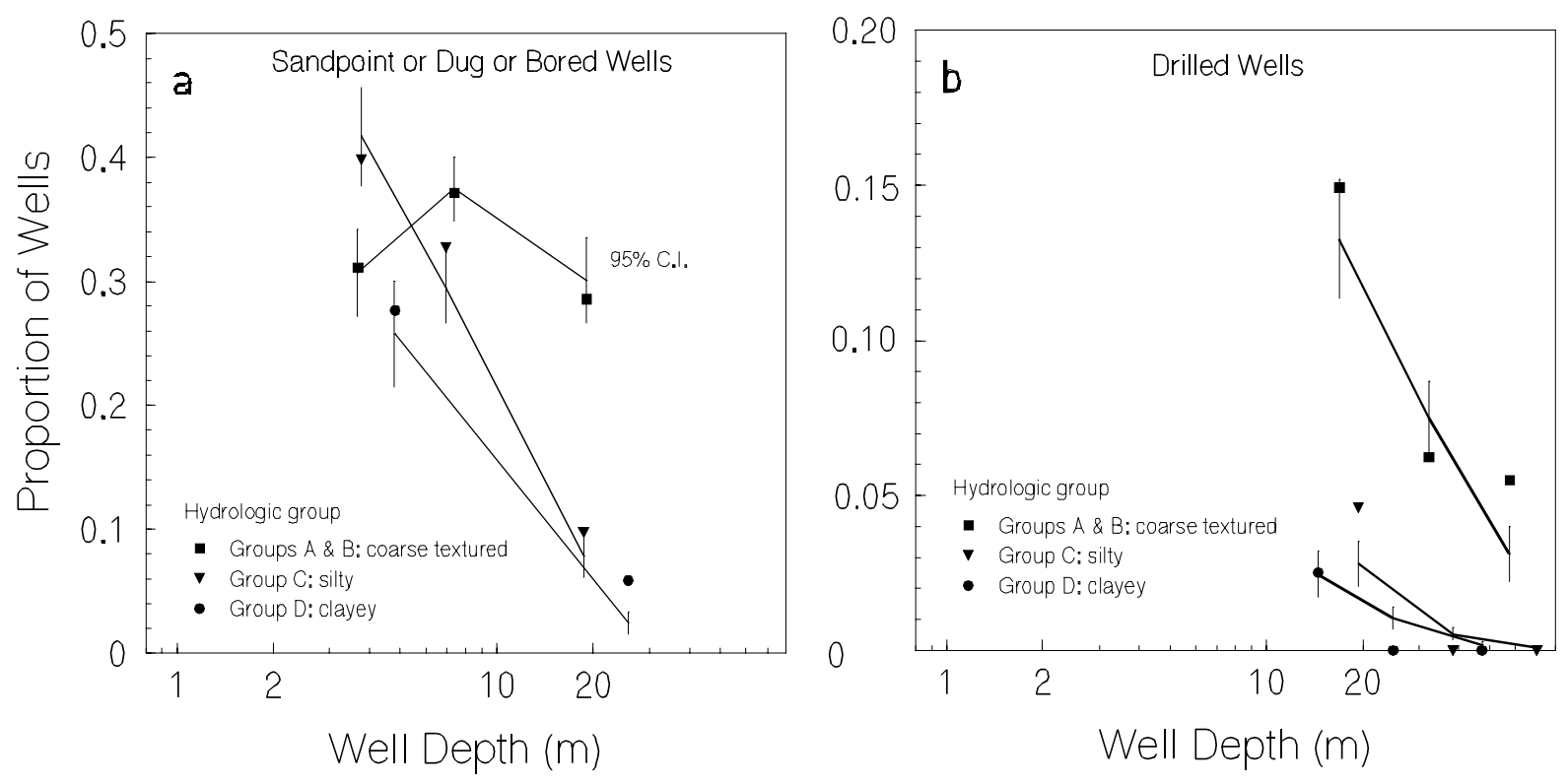

Figure 5 


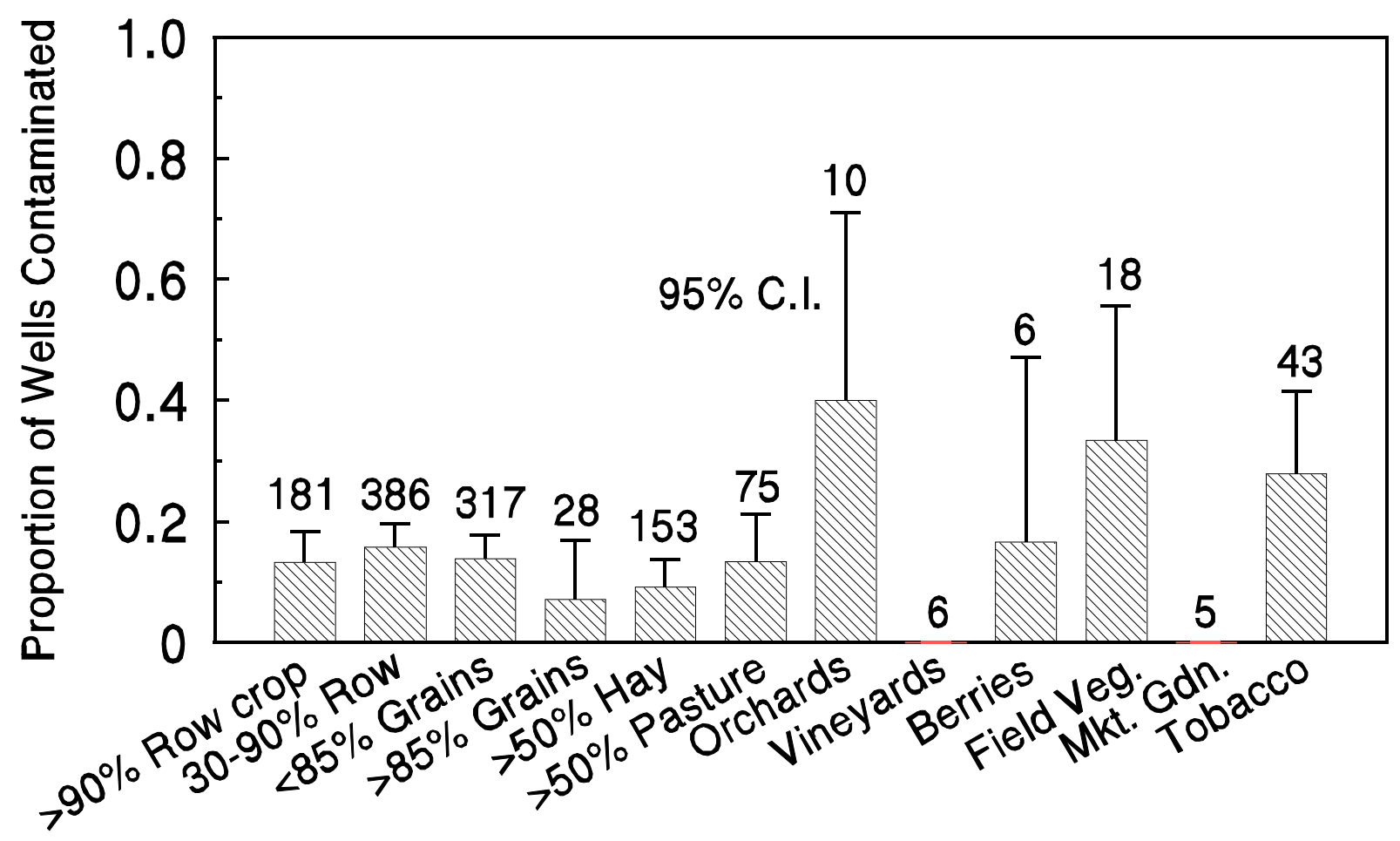

Figure 6 


\section{Figure captions}

2

3 Fig. 1. Cumulative frequency plot for the two major groups of bacterial contamination (faecal and

Fig. 2. Proportion of wells contaminated by nitrate (graphs a and c) and bacteria (graphs b and d) in relation to well type, depth and age. The solid lines shows the transformed logit relationship with $95 \%$ confidence intervals to allow prediction of the variation in the proportion of contaminated wells with depth. The plotted points are the proportion of contaminated wells in the 0.2 depth percentiles of dug or bored wells, and of drilled wells, and the 0.33 depth percentiles of sandpoint wells. The lines in graphs $\mathrm{c}$ and $\mathrm{d}$ show the transformed logit relationships to allow prediction of the variation in the proportion of contaminated wells with depth for wells $5,25,50$, and 100 years old.

Fig. 3. Proportions of wells with detectable levels of atrazine and deethylatrazine. In graph a the solid lines shows the transformed logit relationship with $95 \%$ confidence intervals to allow prediction of the variation in the proportion of wells with depth. The plotted points are the proportion of contaminated wells in the 0.2 depth percentiles of dug or bored wells, and of drilled wells, and the 0.33 depth percentiles of sandpoint wells. The lines in graph b show the transformed logit relationships to allow prediction of the variation in the proportion of wells with depth for wells 5, 25, 50, and 100 years old. 
1 Fig. 4. Proportion of wells contaminated by nitrate or bacteria (total coliform, faecal coliform, or

2 E. coli) in soils of hydrologic groups A (sand and gravel), B (sandy loam), C (silt and silty loam), 3 and D (clay). Error bars indicate the $95 \%$ confidence interval.

5 Fig. 5. Proportion of dug or bored or sandpoint wells (graph a) and drilled wells (graph b)

6 contaminated by nitrate in relation to well depth and soil hydrologic group. The solid lines shows

7 the transformed logit relationship with $95 \%$ confidence intervals to allow prediction of the

8 variation in the proportion of contaminated wells with depth for wells in soil hydrologic group A

9 or B, C, and D. The plotted points are the proportion of contaminated wells in the 0.33 depth

10 percentiles of dug or bored or sandpoint wells, and of drilled wells.

12 Fig. 6. Number of water wells contaminated by nitrate in the winter sampling as a proportion of 13 wells located on farms with the given land-use system. The number at the head of a column is the 14 total number of wells in that land-use system. The error bars indicate the upper bound of the $95 \%$ 15 confidence interval. 
1 Appendix: Parameters of logistic models of well water contamination.

3 Table A1. Regression equations for predicting logit of proportion of wells contaminated by

4 nitrate, based on well type, well age (y)(age), and natural logarithm of well depth (m)(lndepth).

5

\begin{tabular}{lc}
\hline \multicolumn{1}{c}{ Well Type } & Regression Equation \\
\hline Dug/bored or sandpoint & $-3.5+0.006 *$ age $+4.1 * \operatorname{lndepth}-1.86 * 1$ ndepth ${ }^{2}+0.216 * 1 n d e p t h^{3}$ \\
wells & $-3.5-0.74+0.006 *$ age $+4.1 * \operatorname{lndepth}-1.86 * \operatorname{lndepth}{ }^{2}+0.216 * \operatorname{lndepth}^{3}$ \\
Drilled wells &
\end{tabular}

$9 \quad$ Note: $\operatorname{logit}=\ln ($ proportion contaminated/(1-proportion contaminated $))$

10 Regression coefficients and their standard errors are:

11

12

13

14
Terms: Constants Age lndepth $\quad$ lndepth $^{2} \quad \operatorname{lndepth}^{3}$ $-3.5 \pm 1.01 \quad 0.006 \pm 0.0021$

$4.1 \pm 1.34 \quad-1.86 \pm 0.557$

$0.216 \pm 0.0714$ 
1 Table A2. Regression equations for predicting logit of proportion of wells contaminated by

2 bacteria, based on well type, well age (y) (age), and natural logarithm of well depth (m) (lndepth).

3

\begin{tabular}{lc}
\hline \multicolumn{1}{c}{ Well Type } & \multicolumn{1}{c}{ Regression Equation } \\
\hline Dug/ bored wells & $1.63+0.007 *$ age- $0.72 *$ Indepth \\
Sandpoint wells & $1.63-4.66+0.007 *$ age $+(-0.72+1.06) *$ Indepth \\
Drilled wells & $1.63-1.73+0.007 *$ age $+(-0.72+0.29) *$ Indepth \\
\hline
\end{tabular}

7 Regression coefficients and their standard errors are:

Terms: Constant

Age

lndepth

10

$1.63 \pm 0.252$

$0.007 \pm 0.0018$

$-0.72 \pm 0.107$

11

$-4.66 \pm 0.999$

$1.06 \pm 0.487$

$-1.73 \pm 0.448$

$0.29 \pm 0.155$

12 
2 Table A3. Regression equations for predicting logit of proportion of wells with detectable levels

3 of atrazine $\left(\geq 0.05 \mu \mathrm{g} \mathrm{L}^{-1}\right)+$ deethylatrazine $\left(\geq 0.1 \mu \mathrm{g} \mathrm{L}^{-1}\right)$, based on well type, well age (y) (age),

4 and natural logarithm of well depth (m) (lndepth).

5

\begin{tabular}{lc}
\hline \multicolumn{1}{c}{ Well Type } & Regression Equation \\
\hline Dug or bored wells & $-2.73+0.56+0.0067 *$ age $+0.72 *$ Indepth $-0.263 * \operatorname{lndepth}^{2}$ \\
Drilled wells or sandpoints & $-2.73+0.0067 *$ age $+0.72 *$ Indepth $-0.263 * \operatorname{lndepth}^{2}$ \\
\hline
\end{tabular}

$8 \quad$ Regression coefficients and their standard errors are:

9

Terms: Constants

Age

Indepth

Indepth $^{2}$

10

$-2.73 \pm 0.593$

$0.0067 \pm 0.00249$

$0.72 \pm 0.488$

$-0.263 \pm 0.0993$

11

$$
0.56 \pm 0.197
$$

12 
1 Table A4. Regression equations for predicting logit of proportion of wells contaminated by

2 nitrate, based on soil type, well type, well age (y), and natural logarithm of well depth (m).

\begin{tabular}{ll}
\hline Soil type & Regression equation \\
\hline
\end{tabular}

Dug or bored or sandpoint wells

5

6

7

11 Clay

Sands \& loams $\quad-0.92-1.61+0.0021 *$ age $+(0.55+1.29) * 1$ ndepth- $0.44 * \operatorname{lndepth}^{2}$

Silt $-0.92+0.55+0.0021 *$ age $+0.55 * \operatorname{lndepth}-0.44 * \operatorname{lndepth}^{2}$

Clay $-0.92+0.0021 *$ age $+0.55 *$ Indepth- $0.44 * \operatorname{lndepth}^{2}$

Age

Drilled wells

Sands \& loams

$-0.92-1.57-1.61+(0.0021+0.015)$ $-0.92-1.57+0.55+(0.0021+0.015) *$ age $+0.55 *$ Indepth $-0.44 * \operatorname{lndepth}^{2}$

2 Regression coefficients and their standard errors are:

lndepth $\quad$ lndepth $^{2}$

$0.55 \pm 0.467 \quad-0.44 \pm 0.105$

$\begin{array}{lll}-1.57 \pm 0.339 & 0.015 \pm 0.0062 & 1.29 \pm 0.220\end{array}$

$-1.61 \pm 0.501$

$0.55 \pm 0.254$ 